\title{
Integration of CCP Leadership with Corporate Governance
}

Leading Role or Dismemberment?

\section{Xianchu Zhang}

\section{OpenEdition}

\section{Journals}

\section{Electronic version}

URL: http://journals.openedition.org/chinaperspectives/8770

DOI: $10.4000 /$ chinaperspectives. 8770

ISSN: 1996-4617

Publisher

Centre d'étude français sur la Chine contemporaine

\section{Printed version}

Date of publication: 20 March 2019

Number of pages: $55-63$

ISSN: 2070-3449

Electronic reference

Xianchu Zhang, «Integration of CCP Leadership with Corporate Governance », China Perspectives

[Online], 2019-1 | 2019, Online since 19 March 2020, connection on 19 December 2020. URL : http:// journals.openedition.org/chinaperspectives/8770; DOI : https://doi.org/10.4000/chinaperspectives. 8770 


\title{
Integration of CCP Leadership
}

\section{with Corporate Governance}

\author{
Leading Role or Dismemberment?
}

\author{
XIANCHU ZHANG
}

\begin{abstract}
Since 2018, a political campaign to integrate leadership by the Communist Party as the core force in corporate governance in China has reversed the course of market reform in the past 40 years, which was predicated on separation of the Party's political functions from company business operations. This article critically reviews the trend of developments from a historical perspective and analyses the impact of the political campaign on China's socialist market economy and rule of law conditions. Some institutional implications are also examined in the comparative context with reference to the OECD Corporate Principles. The major argument of this article is that enhancing the Party's leadership in companies will negatively affect development of the market economy and rule of law as well as China's attempt to create an innovative society for its economic upgrading.
\end{abstract}

KEYWORDS: China, corporate governance, socialist market economy, economic reform, rule of law, Communist Party.

\section{Introduction}

T he intensified political campaign to strengthen the leadership of the Communist Party of China (CCP) in recent years has spilled over into the arena of corporate governance. As part of the campaign to pave the way for the Constitutional Amendment in early 2018 to insert the CCP leadership as the defining feature of socialism in China, (1) the Organisation Department of the CCP and the State Council issued a circular dated 15 March 2017 ordering institutionalisation of the party's leading functions in all state owned enterprises (SOEs) at all levels by way of amendments to their Articles of Association. In response to the call of the Party-state, all lower governments set out deadlines for implementation, with the model provisions to be included in the Articles of the companies under their supervision. (2) As a result, about $90 \%$ of enterprises with government ownership, including several dozen companies listed overseas, have completed their amendments to formally provide Party organisations with the ultimate power over decision-making and personnel appointment. (3)

The movement soon expanded beyond SOEs to domestic private and foreign investment enterprises, particularly those in new economic sectors, to ensure ideological control and national security. The CCP has demanded that the Articles of these firms include not only a declaration of loyalty, but also an affirmation of the pivotal role of grassroots Party branches in decision-making and business operations. ${ }^{(4)}$ In the latest move, the China Securities Regulatory Commission (CSRC), as the securities market regulator, in September 2018 published its revised Corporate Governance Principles of Listed Companies to replace the 2002 version, including a specific provision that the Party's activities be written into the Articles of state-controlled companies. ${ }^{(5)}$

The recent developments have attracted a great deal of international attention, with the expression of deep concern about China's deviation from the norms and principles of market economy (Allen and Rui 2018). Since corporate governance has become increasingly important in controlling risk in the light of globalised competition, certain norms and principles have been widely accepted, such as the G20/OECD Corporate Governance Principles as amended in 2015 ("OECD Principles") and the OECD Guidelines on Corporate Governance of State-Owned Enterprises of 2015 ("OECD Guidelines"). Both the OECD Principles and the OECD Guidelines set out their objectives "to support economic efficiency, sustainable growth and financial stability" (OECD Principles 2015) and "to ensure positive contribution to economic efficiency and competitiveness." Similarly, the ultimate rationale for state ownership in SOEs is to maximise value for society through an efficient allocation of resources subject to appropriate proce-

1. "Proposed Constitutional Amendment Package Unveiled," Xinhua News Agency, 25 February 2018, http://www.xinhuanet.com/english/2018-02/25/c_136999410.htm (accessed on 28 March 2018).

2. “关于扎实推动国有企业党建工作要求写入公司章程的通知” (Guanyu zhashi tuidong guoyou qiye dangjian gongzuo yaoqiu xieru gongsi zhangcheng de tongzhi, Notice to effectively implement inclusion of the party construction work into company articles of association), Organisation Department of the CCP and State Council, 15 March 2017, http://www.gsj.czs.gov.cn/gzw/ zcfg/content_1198226.html (accessed on 9 January 2018). For example, the deadline for the Xinjiang Autonomous Region was set for 30 December 2017, http://www.xjgzw.gov.cn/info/ 1101/8801.htm; and the deadline for Shandong Province was at the end of September 2017, http://www.rzcjtzjt.com/ctnshow.php/aid/633 (accessed on 21 August 2018).

3. Jennifer Hughes, "China's Communist Party Writes Itself into Company Law," Financial Times, 14 August 2017; Ryan Woo, Kevin Yao, and Stella Qiu, "China's State Forms to Shed Old Corporate Governance Structure by End of 2017," Reuters Business News, 26 July 2017.

4. Simon Denyer, "Command and Control: China's Communist Party Extend Reach into Foreign Companies," Washington Post, 28 January 2018, https://www.washingtonpost.com/world/asia_pacific/command-and-control-chinas-communist-party-extends-reach-into-foreign-companies/20 18/01/28/cd49ffa6-fc57-11e7-9b5d-bbf0da31214d_story.html (accessed on 23 September 2018); Jack Hu and Oiwan Lam, "In Quest for 'Ideological Security', China Pushes to Extend Communist Party Influence inside Tech Firms," Hong Kong Free Press (FP), 10 September 2017, https://www.hongkongfp.com/2017/09/10/quest-ideological-security-china-pushes-extend-communist-party-influence-inside-tech-firms/ (accessed on 28 September 2018).

5.上市公司治理准则 (Shangshi gongsi zhili zhunze, Corporate governance principles of listed companies), CSRC, 30 September 2018, http://www.csrc.gov.cn/zjhpublic/zjh/201809/t20180 930_344906.htm (accessed on 9 November 2018). 
dures of political accountability and transparency (OECD Guidelines 2015). The Chinese government participated in formulating the OECD Principles and OECD Guidelines. It committed to adopting the OECD Principles to all publicly-listed companies. It also expressed the intention to utilise the OECD Guidelines to improve corporate governance of its SOEs, particularly in terms of the independence of SOEs from political influence (International Trade Administration of US (ITA) 2017). In fact, China endorsed the 2015 revised G20/OECD Principles with President Xi Jinping's participation in the G20 Antakya Summit in November 2015 as his gesture of encouraging further reform. ${ }^{(6)}$

Worldwide, corporate governance has been promoted as playing an important role in the development of rule of law and as a benchmark for good governance since the late twentieth century (OECD Principles 2015). According to the World Bank, it has long been accepted that rule of law is an indispensable foundation of market economy and requires a competitive institution with transparency, accountability, checks and balances, and impartiality as its pillars to realise its full social and economic potential (The World Bank 2017). Thus, the formal inclusion of the CCP political leadership into corporate governance in China has sent out a very confusing signal and has triggered serious debate amongst investors, practitioners, and scholars on the direction of China's future legal and economic reform.

With these references in mind, this article critically examines this political movement and its implications from the perspective of market economy and development of rule of law. Part I briefly reviews SOE reform since the late 1970s as a process of struggle; Part II highlights the intensified trend to embed the CCP leadership into corporate governance in recent years; Part III analyses the potential conflicts of the CCP leadership in corporate governance with market discipline and company law; Part IV considers the broader implications to China's development of politicising corporate governance; and Part VI makes some concluding remarks.

\section{A brief review of SOE reform since the 1970s}

The reform of SOEs, a pillar of China's socialism and planned economy, has been a key part of the economic modernisation of China since the late 1970s. Reform experienced a long struggle, with parallel developments in the maintenance of the CCP's political control and ideology and the promotion of market efficiency and discipline.

The original theme of SOE reform in the 1980s was separation of the Party's political control from the business management of enterprises (zheng qi fenkai 政企分开). For instance, a director responsibility system, in which directors are the legal representatives of SOEs and lead the enterprises with comprehensive and uniform responsibilities (changzhang jingli fuzezhi 厂长 经理负责制), was established and promoted by the Party-state in the 1980s. ${ }^{(7)}$ Meanwhile the CCP adopted provisions to define the role of Party organisations in SOEs as actively supporting the decision-making and management of the directors to ensure implementation of Party-state policies under the general principle that the Party secretary should not hold the position of director. ${ }^{(8)}$ The $13^{\text {th }}$ National Congress of the CCP explicitly declared that "the Party's grassroots organisations in enterprises shall no longer practice unified leadership" (bu zai dui ben danwei shixing "yiyuanhua" lingdao 不再对本单位实行 “一元化” 领导). ${ }^{(9)}$ These provisions were further codified into the Law of Industrial Enterprises of the Whole People of 1988 in order to provide the director responsibility system with "legal protection." (10)
The Tiananmen Square Incident changed the course and environment of SOE reform. In 1989, the CCP for the first time required Party organisations within SOEs to be "the political core" in order to prevent "any new political disturbance." (11) This status was later written into the CCP Constitution in 1992 to enable its grassroots organisations in SOEs to participate in the decision-making process for important matters. ${ }^{(12)}$

Soon after, another tidal shift was initiated by paramount leader Deng Xiaoping with the famous Constitutional Amendment in 1993 that officially replaced the old planned economy with so-called socialist market economy. ${ }^{(13)}$ The CCP then decided to reform the SOE-dominated regime with a modern corporation system with clearly defined property rights and liabilities, separation of business operations from politics, and scientific management (chanquan mingxi, quanze mingque, zheng qi fenkai, guanli kexue 产权明晰，权责明确，政企分开，管理科学). (14) Meanwhile, the CCP adopted its policy to adhere to the director responsibility system, ${ }^{(15)}$ and made it clear that the political core of Party organisations in SOEs should not lead to the Party replacing enterprise management. ${ }^{(16)}$ In this period, corporate governance was first acknowledged by the CCP as the core of the modern enterprise system for China's economic modernisation. ${ }^{(17)}$

This round of reform produced a series of positive achievements, including the adoption of the first Company Law and the first Securities Law in PRC history in 1993 and 1998 respectively as the landmarks of introducing a

6. "G20 Leaders Endorse G20/OECD Principles of Corporate Governance," OECD Report, 16 November 2015, http://www.oecd.org/daf/ca/g20-leaders-endorse-g20-oecd-principles-of-corporategovernance.htm (accessed on 4 May 2018)

7. “全民所有制工业企业厂长工作条例” (Quanmin suoyouzhi gongye qiye changzhang gongzuo tiaoli, Director working regulations for enterprises of the whole people), CCP and State Council, 15 September 1986, http://www.gov.cn/gongbao/content/2011/content_1860750.htm (accessed on 3 March 2018).

8. “中国共产党全民所有制工业企业基层组织工作条例” (Zhongguo gongchandang quanmin suoyouzhi gongye qiye jiceng zuzhi gongzuo tiaoli, Provisions of grassroots organisations of the CCP in industrial enterprises of the whole people), 15 September 1986, http://cpc.people.com.cn/ GB/64162/71380/71387/71589/4855239.html (accessed on 3 March 2018).

9. Zhao Ziyang, “中国共产党第十三次全国代表大会工作报告” (Zhongguo gongchandang di shisan ci quanguo daibiaodahui gongzuo baogao, Work Report of the $13^{\text {th }}$ National Congress of the CCP), 25 October 1987, Part 5(1), http://cpc.people.com.cn/GB/64162/64168/64566/65447/ 4526369.html (accessed on 18 April 2018).

10. Art. 7 of the Law.

11. “中共中央关于加强党的建设的通知” (Zhonggong zhongyang guanyu jiaqiang dang de jianshe de tongzhi, Notice of the Central Committee to enhance the Party's construction), 28 August 1989, https://baike.baidu.com/item/\%E4\%B8\%AD\%E5\%85\%B1\%E4\%B8\%AD\%E5\%A4\%AE\% E5\%85\%B3\%E4\%BA\%8E\%E5\%8A\%A0\%E5\%BC\%BA\%E5\%85\%9A\%E7\%9A\%84\%E5\%BB\%BA \%E8\%AE\%BE\%E7\%9A\%84\%E9\%80\%9A\%E7\%9F\%A5/13849382 (accessed on 17 May 2018).

12. “中国共产党章程” (Zhongguo gongchandang zhangcheng, The Constitution of the CCP), CCP, 18 October 1992, Art. 32, http://cpc.people.com.cn/GB/64162/71380/71387/71588/4854 582.html (accessed on 7 February 2018).

13. Art. 6 of the Constitutional Amendment dated 29 March 1993.

14. “中共中央关于建立社会主义市场经济体制若干问题的决定” (Zhonggong zhongyang guanyu jianli shehuizhuyi shichang jingji tizhi ruogan wenti de jueding, Decision of the Central Committee on certain issues concerning the establishment of a system of socialist market economy), 14 November 1993, http://cpc.people.com.cn/GB/64162/134902/8092314.html (accessed on 26 March 2018).

15. “中共中央关于加强党的建设几个重大问题的决定” (Zhonggong zhongyang guanyu jiaqiang dang de jianshe jige zhongda wenti de jueding, Decision of the Central Committee on some major issues concerning enhancing Party construction), 28 September 1994, http://cpc.people.com.cn/ GB/64162/71380/71387/71588/4854612.html (accessed on 15 March 2018).

16. “中共中央关于进一步加强和改进国有企业党的建设工作的通知” (Zhonggong zhongyang guanyu jin yi bu jiaqiang he gaijin guoyou qiye dang de jianshe gongzuo de tongzhi, Notice of the Central Committee on further enhancing and improving Party construction within SOEs), CCP, 24 January 1997, http://cpc.people.com.cn/GB/64162/71380/71382/71383/4844844.html (accessed on 15 March 2018).

17. “中共中央关于国有企业改革和发展若干重大问题的决定” (Zhonggong zhongyang guanyu guoyou qiye gaige he fazhan ruogan zhongda wenti de jueding, Decision on certain major issues concerning SOE reform and development), CCP, 22 September 1999, http://www.people.com.cn /GB/shizheng/252/5089/5093/20010428/454976.html (accessed on 28 December 2017). 
modern enterprise system into China; accession to the World Trade Organisations (WTO) in 2001 with a commitment to market disciplines in which "the government would no longer directly administer the human, finance and material resources, and operational activities such as production, supply and marketing," (WTO 2001); and the promulgation of China's first set of Corporate Governance Principles of Listed Companies in 2002, including rules on protecting investors' rights, fair dealing among majority and minority shareholders, and professional responsibilities. ${ }^{(18)}$ These developments not only provided significant momentum for the country's economic taking-off, but also transformed most SOEs into market-oriented corporations. According to the results of the Second National Economic Survey published at the end of 2009, the number of SOEs dropped from 369,000 in 2001 to 143,000 , and counted for less than $3 \%$ of China's 4.96 million enterprises. ${ }^{(19)}$ However, the development of the socialist market economy has never prevented the Party-state from "heavily intervening in a broad range of decisions related to the strategies, management, and investments of state-owned enterprises," particularly after the establishment of the State-Owned Assets Supervision and Administration Commission (SASAC) as the Party-state agency for SOE corporate governance in 2003 (United States Trade Representative 2015). The SASAC has thus far not only set out numerous regulations for the operation and management of SOEs, but has also developed a very sophisticated network to promote party-state ideology and policies from the central to the local levels (Lin and Milhaupt 2013). Its working emphasis soon shifted from improving SOE efficiency with diversified ownership in its early years to repositioning the state sector with high market concentration to make it bigger and stronger under the CCP's so-called national champion strategy emphasising national political security and economic safety. ${ }^{(20)}$

In this process, SOE market monopolies have been further enhanced with consolidation of the gigantic SOEs under the direct control of the central government, known as the central enterprises (yangqi 央企). In 2017, the total assets and turnover of central enterprises reached RMB 55 trillion, a $73.8 \%$ increase over 2012, and RMB 26.4 trillion, or 33\% of that year's national GDP. Out of 97 central enterprises, 48 ranked in the World Top 500. (21) Meanwhile, 1,003 state-controlled listed companies accounted for $44 \%$ of the entire value of China's securities market (Liao 2017), not to mention the holdings of various investment funds under state control, known as "the national teams" (guojiadui 国家队), accounting for another $7.4 \%$ of market value. ${ }^{(22)}$

Political ideology is also reflected in major legislation. For example, the 2005 amendments to the Company Law further mandated that enterprises, regardless of their ownership, must provide CCP grassroots organisations with "necessary working conditions." (23) Further, the Law on the State-Owned Assets of Enterprises of 2008 stipulates the SASAC's function as a special investor in enterprises with state investment on behalf of the government at all levels, including decision-making rights on important matters, management selection, formulation of articles of association, and the legal obligation to increase the value of state assets and prevent them from being lost. (24)

The repositioning of the state sector has also played out in the phenomenon of "the state advances, the private sector retreats" (guo jin min tui 国进民退), wherein SOEs have expanded their market monopoly by aggressively taking over private businesses with their political power and unfair terms (Yang and Jiang 2012; Johansson and Feng 2016). In this process, quite a few private entrepreneurs were convicted of unlawfully raising capital, competing with SOE-controlled sectors in violation of state policy, and alleged embezzlement of SOE assets. (25)
Such developments have not only extinguished the momentum of SOE reform for more than 10 years, ${ }^{(26)}$ but have also resurrected traditional SOEstyle governance. The CCP and the SASAC have demanded that Party organisations in SOEs maintain high consistency with the Party's political lines and actively explore means of participating in major decision-making in SOEs by way of cross-linked positions of Party leaders and senior management. (27) In 2010, the CCP and the State Council further promoted a socalled "three majors and one large" system (sanzhong yida 三重一大), in which all major decision-making, major personnel appointments, the adoption of major projects, and large capital operations of SOEs must be decided with the participation of Party committees, with Party secretaries as the principal responsible persons. ${ }^{(28)}$

The above brief review of SOE reform and the development of corporate governance in China as a socialist market economy since the late 1970s has provided a showcase of legal and ideological struggle in an uncertain course charted by CCP policies. Despite some significant progress, the CCP's political control has never gone away. As such, reform that has merely oscillated between market economy and political authoritarianism has proved insufficient to effectively improve corporate governance in China. Since 2003, with the Party-state's support, the state sector that survived reform and financial crisis has even made a dynamic come-back with stagnation of the reform process. According to a joint assessment by Protiviti and the Chinese Academy of Social Sciences in 2012 of the top 100 listed companies in China with OECD Corporate Governance Principles, the average score was 65.9 out of 100 , showing a considerable gap with the norms and practices recommended by the Principles, particularly in terms of shareholder rights protection, board

18. The Principles were promulgated by the China Securities Regulatory Commission and the State Commission of National Economy and Trade, 7 January 2002. An English translation is available at http://www.legaltranz.com/archives/356 (accessed on 7 April 2018).

19. “第二次全国经济普查主要数据公报 - - 第一号” (Di'er ci quanguo jingji pucha zhuyao shuju gongbao - Di yi hao, Bulletin of major data of the second national economic survey (1)), The Bureau of National Statistics of China, 25 December 2009, http://www.stats.gov.cn/tjsj/tjgb /jjpcgb/qgjpgb/201407/t20140731_590163.html (accessed on 4 May 2018).

20. “中共中央关于完善社会主义市场经济体制若干问题的决定” (Zhonggong zhongyang guanyu wanshan shehuizhuyi shichang jingji tizhi ruogan wenti de jueding, Decision of the Central Committee on certain issues concerning improvement of the socialist market economy), 14 October 2003, http://www.lawinfochina.com/display.aspx?lib=law\&id=3240\&CGid (accessed on 15 May 2018).

21. Report of the Xinhua News Agency, 20 February 2018, http://www.xinhuanet.com/fortune/201802/20/c_1122431123.htm (assessed on 25 April 2018).

22. Li Lifeng, “国家队是A股不可忽略的特殊力量” (Guojiadui shi A gu buke hulue de teshu liliang, The national team is a special non-negligible force), Jinrong Jie (Financial Sector), 4 May 2018, http://stock.jrj.com.cn/invest/2018/05/04133924492815.shtml (assessed on 10 May 2018).

23. Art. 19 of the Company Law as amended in 2005.

24. Arts. 11, 12, 14 and 15 of the Law on State-Owned Assets of Enterprises of 2008.

25. Yang Junfeng, "Crowded Out," China Economic Review, 15 October 2012; an Interview by Global Times with Prof. Liu Junhai on Private Entrepreneurs Cases, 23 April 2013. Website of the Rules of Law in China Capital Market: http://www.chinacapitallaw.com/article/default.asp?id=11124.

26. “国务院专家：国企改革近十年无进展” (Guowuyuan zhuanjia: guogi gaige jin shinian wu jinzhan, State Council experts: No progress made in SOE reform for almost 10 years), Huaxia Shibao 华夏时报 (China Times), 14 November 2014.

27. “中央组织部、国务院国资委党委关于加强和改进中央企业党建工作的意见” (Zhongyang zhuzhi bu, guowuyuan guoziwei dangwei guanyu jiaqiang he gaijin zhongyang qiye dangjian gongzuo de yijian, Opinions of the Organisation Department of the CCP and the Party Committee of the SASAC on enhancing and improving party-building work in the central enterprises), 31 October 2004, http://cpc.people.com.cn/GB/64162/71380/102565/182143/10993484.html (accessed on 9 March 2018)

28. “关于进一步推进国有企业贯彻落实“三重一大”决策制度的意见” (Guanyu jinyibu tuijin guoyou qiye guanche luoshi "sanzhong yida" juece zhidu de yijian, Opinions on further promoting implementation of "the three majors and one large" decision-making system), General Office of the CCP and the General Office of the State Council, 15 July 2010, http://www.gov.cn/jrzg/201007/15/content_1655395.htm (accessed on 23 April 2018). 
function, and mechanisms to deal with conflict of interest. (29) This is the background against which the new round of SOE reform was launched after Xi Jinping took office.

\section{New movements in the Xi era}

The struggles of SOE reform have continued under Xi Jinping's leadership. Some renewed endeavour toward reform was reflected in the CCP Decision adopted in 2013 ("the Reform Decision") to comprehensively deepen reform by letting the market play a decisive role in resource allocation. As far as SOE reform was concerned, the Decision clearly stated that SOEs should be further reformed with a better definition of their functions on the basis of market competition and protections of the property rights of enterprises with different kinds of ownership. ${ }^{(30)}$ A year later, the CCP further adopted a decision to promote the rule of law for national political and economic development. The Decision set out the goals of effectively protecting property and contract rights, and promoting equal competition among companies with different ownership within a unified market. (31)

The CCP decisions have produced some positive results, such as a further amendment of the Company Law to abolish the minimum statutory capital requirement in 2013, (32) and the promotion of mixed ownership to let SOEs bow out of some competitive business sectors. ${ }^{(33)}$ The State Council further set out a mandatory time limit for all SOEs to complete their transformation, i.e., the end of 2017. (34) It was reported that approximately $97 \%$ of central and local SOEs completed their incorporation work by January 2018. ${ }^{(35)}$

Despite the encouraging signs, it is not necessary to read between the lines to find a continuation of inherent contradictions and conflicts between political ideology and market disciplines in the new round of reform. In the Reform Decision, apart from the call for further marketisation of SOEs, heavy emphasis was placed on upholding socialism and the CCP's leadership. It was explicitly stated that the general purpose of the comprehensive reforms was to develop socialism with Chinese characteristics and to fashion Party-state governance. As such, all reform must be carried out under the close embrace of CCP leadership as the political core to control the design and overall situation of reform. ${ }^{(36)}$

In fact, political campaigns to strengthen party leadership in enterprises have been carried out at a higher intensity than market reforms in recent years. Since 2013, at least a dozen Party-state documents have been issued for this purpose, with heavy emphasis on firmly adhering to party leadership in SOEs. For instance, the top CCP leadership group adopted the Opinions on Adhering to CCP Leadership and Enhancing Its Construction in Deepening SOE Reform (the Opinions) in June 2015, in which the CCP leadership was characterised as the unique advantage of SOE competitiveness, and thus adherence to it had to be built into the process of SOE reform. In particular, the Opinions for the first time mandated the integration of the Party leadership enhancement with corporate governance improvement through a clear identification of the legal status (fading diwei 法定地位) of the Party leadership, its control over SOE senior officers, and its more active role in SOE operation. (37)

A circular issued by the Party-state in 2013 further specified that Party organisations had to be involved in decision-making in important matters of SOEs, including adopting development strategies, operational policy, mergers and acquisitions, selection of mid-level management, and Party control over personnel matters (dang guan ganbu/dang guan rencai 党管 干部/党管人才). It explicitly provided that Party committees should be consulted on all important motions before they are submitted to the board of directors. (38)

More detailed guidelines promulgated by the CCP and the State Council in 2015 made it clear that the guiding ideology of SOE reform should be upholding socialism to make SOEs stronger, better, and bigger, and maintaining the controlling position of central enterprises in all the key business fields that involve national security and economic lifelines. Moreover, the Party-state demanded an innovation in the core political role it plays in SOEs by introducing a cross-appointment system for Party leaders and director and senior officer positions (shuangxiang jinru, jiaocha renzhi, 双向 进入, 交叉任职), and as a general principle the Party secretary shall be appointed the chairman of the board of directors. As such, Party leaders hold all key positions and decision-making power through "double (political and management) responsibilities" (yi gang shuang ze 一岗双责) and "their sense of political loyalty" (zhongcheng yishi 忠诚意识). (39) The mandates were further endorsed by the State Council in 2017, when Party committees were ensured control of the direction, overall operation, and implementation of SOEs (bao fangxiang, guan daju, bao luoshi 保方向，管大局， 保落实). (40) More recently, the campaign to institutionalise Party leadership through amendments to the Articles further demonstrates the CCP's longterm political agenda.

29. “甫瀚咨询发布2012年中国上市公司治理评价报告” (Puhan Zixun fabu 2012 nian Zhongguo shangshi gongsi zhili pingjia baogao, Protiviti issues its 2012 assessment report on corporate governance of Chinese listed companies), PR Newswire, 28 June 2012, https://www.prnasia.com/ story/64346-1.shtml (accessed on 13 August 2018).

30. “中共中央关于全面深化改革若干重大问题的决定” (Zhonggong zhongyang guanyu quanmian shenhua gaige ruogan zhongda wenti de jueding, Decision of the Central Committee on certain major issues concerning comprehensively deepening reform), 12 November 2013, http://www.gov.cn/jrzg/2013-11/15/content_2528179.htm (accessed on 26 May 2018).

31. “中共中央关于全面推进依法治国若干重大问题的决定” (Zhonggong zhongyang guanyu quanmian tuijin yifa zhiguo ruogan zhongda wenti de jueding, Decision of the Central Committee on comprehensively moving forward governing the country according to the law), 23 October 2014, http://cpc.people.com.cn/n/2014/1029/c64387-25927606.html (accessed on 3 April 2018).

32. The Decision of the Standing Committee of the National People's Congress (NPC) on Amendments to the Company Law and Six Other Laws, Dec. 28, 2013, Part 7.

33. The Opinions of the State Council on Further Optimising the Market Environment for Enterprise Mergers and Acquisitions, promulgated on 24 March 2014, Items 22 and 23.

34. “国务院办公厅关于印发中央企业公司制改制工作实施方案的通知” (Guowuyuan bangongting guanyu yinfa zhongyang qiye gongsi gaizhi gongzuo shishi fang'an, Notice of the General Office of the State Council on printing and distributing the Implementation plan to transform central enterprises), 18 July 2017, http://www.gov.cn/zhengce/content/2017-07/26/content _5213271.htm (accessed on 23 March 2018).

35. “國企改革進展佳" (Guogi gaige jinzhan jia, Good progress made in SOE incorporation), Wen Wei Po (Hong Kong), 16 January 2018, A16.

36. CCP Decision, supra note 32. See Part 1(2) and Part. 16

37. “中共中央全面深化改革领导小组关于在深化国有企业改革中坚持党的领导加强党的建设的 若干意见” (Zhonggong zhongyang quanmian shenhua gaige lingdao xiaozu guanyu zai shenhua guoyou qiye gaige zhong jianchi dang de lingdao jiaqiang dang de jianshe de ruogan yijian, Certain opinions of the CCP leader group for deepening reform on adhering to the Party leadership and enhancing Party construction in deepening SOE reform), 5 June 2015, http://www.SXdj.gov.cn/focus/guoqidangjian/Untitled-1.html (accessed on 12 February 2018).

38. “国务院国资委党委关于中央企业党委在现代化企业制度下充分发挥政治核心作用的意见” (Guowuyuan guoziwei dangwei guanyu Zhongyang qiye dangwei zai xiandai qiye zhidu xia chongfen fahui zhengzhi hexin zuoyong de yijian, Opinions on the Party committee of central enterprises to fully play their political core functions in the modern enterprise system), The Organisation Department of the CCP and the Party Committee of the SASAC, April 2013, http://xtkg.hnfun.com/upload/files/2016/6/2916352500.docx (accessed on 18 January 2018).

39. “中共中央国务院关于深化国有企业改革的指导意见” (Zhonggong zhongyang guowuyuan guanyu shenhua guoyou qiye gaige de zhidao yijian, The guiding opinion of the Central Committee and State Council on deepening SOE reform), 24 August 2015, http://www.gov.cn/zhengce/201509/13/content_2930440.htm (accessed on 12 March 2018).

40. Sec. 1(2) of the Guiding Opinions on Further Improving Corporate Governance of SOEs dated 24 April 2017. 
Integration of Party leadership with corporate governance was soon celebrated as a "significant institutional innovation" (41) for: (1) upgrading the core role of Party organisations to overall leadership; (2) officially giving up the reform theme of party-enterprise separation with further legitimation of linking SOE management with the Party's political lines; (3) further fixing the Party's status through mandated provisions of company Articles of Association; (4) officially mandating interlocked positions to ensure the party's decision-making control for the first time, and (5) vigorous expansion of the political campaign to the private sector for the first time since the economic reform in the late 1970s. As such, the direction of the longstanding reform has been reversed, and "the prospects for enduring corporate governance reform in China appears gloomier than ever" (Song 2017).

\section{Conflicting interests in corporate governance}

The political campaign described above has sent out very confusing messages concerning the development of China's socialist market economy. On the one hand, China has accepted the OECD Principles and vigorously fought for international recognition of its status as a full market economy. ${ }^{(42)}$ On the other hand, the return of SOEs, with the Party leadership as a core element of corporate governance, clearly demonstrates a significant change in the prevailing theme of reform over the past three or four decades, which was to separate party politics from SOE business management. The conflicting developments further reflect the unique character of corporate governance challenges in China.

In the first place, Party-state ideology and political considerations may inevitably conflict with the OECD Principles of economic efficiency, sustainable growth, and accountability. At the recent National Party Construction Conference of SOEs, Xi Jinping stated that Party leadership in SOEs "aims at making them the most reliable force of the Party-state to firmly implement its deployment" (Xi 2016). This political ideology is in apparent conflict with market discipline and other shareholders' interests. In reality, this priority has been realised at the cost of market efficiency. According to a recent study by the Unirule Institute of Economics (Tianze jingji yanjiu suo 天则经济研究所), the average net assessed return of the entire state sector in 2001-2013 was 9.08\%, much lower than that of the non-state sector, which was $15.67 \%$; and state financial subsidies to SOEs in 19942007 amounted to RMB 639.4 billion (Unirule Institute of Economics 2016). Even some huge central SOEs that monopolised the market had to rely on heavy government subsidies to make up for their losses. ${ }^{(43)}$

Secondly, the enhancement of Party leadership in SOEs may have a negative impact on market transparency and equal competition. The Partystate's policy of making SOEs better, bigger, and stronger may adversely affect the competitive environment for other market players. Since SOEs marched back to the market in the early 2000s, three phenomena have been observed: (1) private sector investment has declined from an average of $20 \%$ in the 2000 s to just $1.2 \%$ in July $2016 ;{ }^{(44)}(2)$ in the past 15 years, Chinese investment emigration, mainly by rich entrepreneurs, has grown dramatically. Nearly two-thirds of wealthy entrepreneurs with assets of more than 1.5 million of US dollar surveyed by Hurun Research Institute in 2014 had either already participated in investor visa programs or were considering their migration plans (Tian 2017); and (3) mixed ownership programs have attracted limited interest from the private sector due to serious worries about political control and the lack of a level playing field. ${ }^{(45)}$ In a sense, these phenomena can be viewed as votes of insecurity and noncon- fidence in the current regime and policy. Moreover, there have been warnings that because of ideological struggle, mixed ownership schemes cannot effectively resolve the corporate governance problems of SOEs (Milhaupt and Zheng 2016), particularly when they are intended "to rationalise the state sector position and reinforce the state sector's capacity for control, market influence, and risk resistance." (46)

Thirdly, the mandatory amendment of the Articles of Associations of corporations to stipulate Party leadership will trigger deep concerns over the protection of minority shareholders in both Party-state-controlled firms and other companies where the Party organisation may play a role disproportionate to their interest percentage. Quite a few Chinese companies listed in Hong Kong have seen strong resistance to such article amendments, with more than $10 \%$ voting against the proposals concerned. For example, almost $39 \%$ of shares issued in Hong Kong ( $\mathrm{H}$ shares) represented at the general meeting of the Industrial and Commercial Bank (ICBC), the largest bank in the world, voted against the change. In the case of Chongqing Iron \& Steel, the opposing votes of $\mathrm{H}$ shares in the general meeting exceeded $70 \%$. Such strong opposition has even forced some companies to be listed overseas without sufficient state controlled shares to suspend their amendments in order to avoid defeat (Allen and Rui 2018). In a surprising incident, the minority shareholders of Tianjin Real Estate Group (Tianfang jituan 天房集团), a Shanghai listed company where the single SOE majority shareholder controlled $26.74 \%$ of the total shares, voted down the proposal to insert Party leadership into the company's Articles of Association in its general meeting in January 2017. The study revealed that $91 \%$ of the remaining small shareholders with holdings of less than $5 \%$ voted against the proposal, which clearly showed the degree of their antagonism (since abstaining from the vote would lead to the same result). ${ }^{(47)}$

This rebellion of the company was eventually dealt with by another general meeting in May 2017, during which the board of directors called for the collection of proxy votes in advance. According to Article 31 of the General Meeting Rules of Listed Companies in China, a shareholder with an interest in the proposed matter should recuse him/herself from voting;

41. Commentary by the Xinhua News Agency, “党的领导和公司治理相结合是重大创新” (Dang de lingdao he gongsi zhili xiang jiehe shi zhongda chuangxin, Integration of Party leadership with corporate governance is a significant innovation), Xinhua News Agency, 22 September 2015, http://www.xinhuanet.com/politics/2015-09/22/c_128255492.htm (accessed on 24 October 2018).

42. Ni Hongfu, "China's Development Deserves Market Economy Status," People's Daily, 20 December 2017, http://en.people.cn/n3/2017/1220/c90000-9306563.html (accessed on 2 November 2018).

43. Kenneth Rapoza, "China's State Owned Enterprises Still Losing Money," Forbes, 15 July 2016, https://www.forbes.com/sites/kenrapoza/2016/07/15/chinas-state-owned-companies-still-losing-money/\#54fbb0523b4e (accessed on 24 October 2018).

44. Zhao Jun, "Three Risks to Chinese Economy," World Economic Forum, 2 November 2016, https://www.weforum.org/agenda/2016/11/three-risks-to-the-chinese-economy (accessed on 19 May 2018)

45. Wang Shuguang, "Mixed-Ownership Reform Needs to Level Playing Field," Global Times, 7 March 2017, http://www.globaltimes.cn/content/1036349.shtml (accessed on 2 December 2018); Gabriel Wildau, "Chinese Reform Plans Highlights Reluctance to Cede Control," Financial Times, 9 January 1997, https://www.ft.com/content/bcc8ea42-d3d7-11e6-9341-7393bb2e1b51 (accessed on 12 August 2018).

46. “关于国有企业发展混合所有制经济的意见” (Guanyu guoyou qiye fazhan hunhe suoyouzhi jingji de yijian, Opinions on developing mixed ownership economy), State Council, 25 September 2015, http://www.mohrss.gov.cn/SYrlzyhshbzb/dongtaixinwen/shizhengyaowen/201509/t2015 0925_221484.htm (accessed on 4 February 2018).

47. Wang Yonghua, “明确国企党组织在公司治理中的法定地位” (Mingque guoqi dang zuzhi zai gongsi zhili jiegou zhong de fading diwei, Identifying the legal status of the Party organisations in corporate governance of SOEs), Faren (法人, Legal Persons), 21 October 2017, http://www.farennews.com/yw/6800_2.html (accessed on 2 May 2018); Alice Yan, "Chinese Company Shareholders Vote 'No' to Corporate for Communist Party," South China Morning Post, 14 January 2017, https://www.scmp.com/news/china/policies-politics/article/2062061/chinese-company-shareholders-vote-no-corporate-role (accessed on 2 May 2018) 
sufficient disclosure of information should be made to the shareholders concerned; and minority votes should be counted separately if the matter may significantly affect their interest. ${ }^{(48)}$ Nevertheless, the board's proxy call simply stated that setting out the Party's legal status as part of corporate governance in its Articles was a reflection of the company's lawful operation and enabled the Party to play its core role. ${ }^{(49)}$ As a result, the Party committee not only ensured the board of directors' passage of the Article amendment empowering it to review all important matters before they are submitted to the board, but also realised "comprehensive" Party leadership of all levels of the company within just five months. (50)

Fourthly, integration of the Party leadership with corporate governance may further complicate the already overloaded legal framework and its rational function. The corporate governance structure in China has long been criticised for its over-complexity, with not only a German-style supervisory board, USinvented independent directors, former Soviet Union-style workers' assembly, British-type taking-over rules, and Chinese Party-state establishments (Zhang 2012), but also discordant relations between the board of directors, supervisory board, and shareholders meeting under the new formal governance structure (xinsanhui 新三会), standing side-by-side with the Party committee, trade union, and workers' assembly under the old SOE framework (laosanhui 老三会) (Gore 2011). Thus far the system has not functioned well due to internal conflicts, guanxi (关系)-based culture, and political intervention.

In this environment, strengthening the Party leadership in enterprises may further subject the chairman and the board to divided Party and fiduciary loyalties, and divided professional standards toward their companies and shareholders. Moreover, Party participation might further intensify existing institutional conflicts. For example, as part of the effort to improve corporate governance, the State Council has mandated SOEs to fully establish a board system with outsider directors as the majority. ${ }^{(51)}$ However, minority insider directors, who are cross-appointed from the Party committees, will definitely have more control and decision-making power to ensure the correct political line of the Party-state as their top priority, as opposed to outside directors, who are legally supposed to play a role independent from the majority shareholders and serve as de facto controllers to protect the interests of the company, both as a whole and of the minority shareholders. ${ }^{(52)}$ In this regard, a wave of resignations was observed recently: at least 134 independent directors left their positions in the second half of 2016, citing institutional restrictions on the exercise of their independent power as the major reason. ${ }^{\left({ }^{3} 3\right)}$ As such, it is by no means certain to what extent the interests of the Party-state shareholders and other (minority) shareholders can be truly and fairly united. The board may not actually represent and protect the interest of all shareholders, while the supervisory board, as watchdog of the company, may effectively supervise the Party committee's exercise of power over the company.

Fifthly, the strong Party presence in enterprises may add challenges and difficulties to the accountability and enforcement of corporate governance. According to the policies and provisions mentioned above, a company board under Party leadership is required, in performing its duties, to first adhere to the Party-state before considering business principles, including due diligence and prudence. This apparently goes beyond the power and jurisdiction of enforcement agencies. As such, laws and regulations may not be strictly enforced with a full accounting of liabilities if certain decisions or activities are directed by Party committees for any political purpose.

Moreover, such party-enterprise relations may have a fenced-off effect against strict enforcement. Thus far, on market enforcement, SOEs still enjoy special privileges, particularly with respect to market discipline and legal liabilities. For instance, for a long time bankruptcy law in China could not be effectively implemented due to the political protection of SOEs and the priority placed on maintaining social stability (Wei 2017). Studies also find that state-controlled companies received fewer sanctions on securities market enforcement than private firms due to their relations with the partystate and various political considerations (Berkman, Cole, and Fu 2011). In this context, the Party's strong leadership may further complicate the enforcement and disrupt equal competition in the market.

Last but not least, expansion of Party leadership to private enterprises has raised serious concerns and controversy. According to the CCP, in addition to SOEs, the campaign to enhance Party leadership has also marched into the private sector. By the end of 2016, Party organisations had been established in $67.8 \%$ of 2.73 million domestic private enterprises and $70 \%$ of 106,000 foreign investment enterprises. Due to the state mandate, Party establishment and leadership have virtually become a condition of market access to China for foreign investment firms over and above the Company Law and OECD Principles. ${ }^{(54)}$ It is the CCP that writes itself into corporate governance through its internal provisions rather than any clear legal rules. Article 2 of the Working Provisions of CCP Organisations explicitly empowers CCP establishments to play a "core leading role" in, inter alia, all economic organisations, regardless of their ownership. ${ }^{(55)}$

This political campaign has met with strong resistance in the private sector. In addition to domestic incidents such as shareholders' refusal and entrepreneurs' lack of confidence, as reflected above, the Delegations of German Industry and Commerce in China stated that German investment enterprises in China might "retreat from the Chinese market or reconsider investment strategies" if such attempts continued. ${ }^{(56)}$ The EU Chamber of Commerce in China also demanded that foreign investment enterprises be treated differently from SOEs, and argued that the corporate governance established by the Company Law and joint venture laws of China, giving the board of directors the highest executive authority, should not be changed in such a dramatic way. ${ }^{(57)}$

48. “上市公司股东大会规则” (Shangshi gongsi gudong dahui guize, General meeting rules of listed companies), CSRC, as amended in 2013, http://www.csrc.gov.cn/pub/zjhpublic/zjh/ 201410/P020141024531452811911.pdf (accessed on 18 April 2018).

49. “天房发展：提案将再闯关” (Tianfang fazhan: Ti'an jiang zai chuangguan, Tianjin real property development: Making breakthrough again), Zhengquan Shibao (证券时报, Securities Times), 19 April 2017, http://stock.jrj.com.cn/2017/04/19192122349687.shtml (accessed on 3 September 2018).

50. Tom Mitchell, "China's Communist Party Seeks Company Control before Reform," Financial Times, 15 August 2017, https://www.ft.com/content/31407684-8101-11e7-a4ce-15b2513cb3ff (accessed on 10 August 2018).

51. State Council, supra note 49

52. Principles of Corporate Governance of Listed Companies

53. Liu Fan, "独董辞职潮" (Dudong cizhichao, A wave of independent director resignations), Zhengquan Shibao (证券时报, Securities Times), 29 November 2016, http://www.stcn.com/ 2016/1129/12959792.shtml (accessed on 1 June 2018).

54. “中國私企設立中共黨支部” (Zhongguo siqi sheli zhonggong dang zhibu, The CCP grassroots organisations established in private enterprises in China), Aboluo News (阿波罗新闻), 22 October 2017, http://www.aboluowang.com/2017/1022/1012976.html (accessed on 24 April 2018).

55. “中国共产党党组工作条例 (试行)” (Zhongguo gongchandang dangzu gongzuo tiaoli (shixing), Working provisions of the CCP organisations (For trial implementation)), Xinhuanet, 11 June 2015, http://www.xinhuanet.com/politics/2015-06/16/c_1115638059_2.htm (accessed on 25 May 2018).

56. He Huifeng, "German Trade Body Warns Firms May Pull out of China over Communist Party Pressure," South China Morning Post, 29 November 2017, https://www.scmp.com/news/china/economy/article/2122104/german-trade-body-warns-firms-may-pull-out-china-over-communist (accessed on 2 January 2019).

57. EU Chamber of Commerce in China, "Chamber Stance on the Governance of Joint Ventures and the Role of Party Organisations," Press Release, 3 November 2017. 
A critical examination shows that enhancement of Party leadership has not only reversed the direction of SOE reform, but has also had a negative impact on the entire market with respect to improving corporate governance, market efficiency, strict enforcement and accountability, fiduciary duty to avoid conflict of interest, and effective protection of the interests of shareholders as a whole in compliance with OECD Principles.

\section{Further implications}

The integration of Party leadership with corporate governance is not an isolated movement, but an important part of the recent political campaign to enhance the CCP's overall leading position in the entire country, together with the constitutional amendment to confirm the Party leadership as the most fundamental element of Chinese socialism, and the departure from Deng Xiaoping's original advocacy of separating the Party from the state and the market. ${ }^{(58)}$

Given that China has been a socialist country for almost 70 years, since 1949 , the path dependence theory may not view this political development as a big surprise. What is interesting is the reorientation of the attack toward some major achievements of the reform. Since 1993, when the principle of socialist market economy was written into the Constitution, the Party-state has vigorously promoted the establishment of a modern enterprise system as an effective means of SOE reform, and has carefully tried to balance corporate governance rules with the Party's political ideology, despite its wariness of the market and civil society institutions (Clarke 2010). As observed by the Asian Corporate Governance Association, from the early 1990s, "[t]he dominant corporate governance reform trend in China was towards global standards," with the government's avid participation in international developments until the attitude change after the worldwide financial crisis (Allen and Rui 2018). After Xi Jinping delivered his speech at the 2016 National Party Construction of SOEs, directing heavy criticism at the weakening, fading, and marginalisation of Party leadership in SOEs, the trend has apparently been reversed. Some official media articles have openly claimed that, in the first 30 years of SOE reform, Party leadership was damaged in the process of learning the modern enterprises system, with the Western corporate governance structure damaging SOE development. ${ }^{(59)}$ In this context, rights-based corporate governance is viewed more as a threat to the political regime than as enabling institutions. Recently, the official journal of the Communist Party even published an article stating that eliminating private ownership should never be forgotten as the mission of the Communist Party, despite allowing for mixed ownership during the transitional period. ${ }^{(60)}$

The economic reform of the past 40 years has significantly changed China as well as the Communist Party. Despite the economic achievements, the Party-state has remained wary of the political implications of market demands for efficient competition, diversified ownership, and market freedom and equality. In a sense, the Party's concern is justified when it observes how market forces have weakened and diminished the organisational monopoly, extensive embeddedness in society, and functional rule at the micro-level that it has enjoyed since 1949 (Gore 2011).

Against this backdrop, it may not be too difficult to understand Xi Jinping's characterisation of SOEs as "the important material and political foundation" of China's socialism and the Party's leadership as the "roots and soul" of SOEs to make them the most reliable force of the party-state. As a result, any weakening, fading, blurring, or isolation of the Party's role in SOEs has to be dealt with comprehensively (Xi 2016). Thus, "the first and foremost reason" for the
Party-state to reset party-enterprise relations with its overall and visible control in enterprises (Wang 2014: 660) is to prevent the encroachment of the market economy, even if this is apparently contradictory to the objectives of the OECD Principles and corporate law under market discipline to advance the aggregate welfare of all stakeholders affected by the companies' activities with higher conflict-response efficiency, inter alia, between management and shareholders, as well as between controlling and non-controlling shareholders (Armour, Hansmann, Kraakman and Pargendler 2017). Thus, the principle of Party leadership may inevitably assign much greater weight to safeguarding the Party-state's interests than to the principle of corporate governance, and this can lead to more conflict and contradiction between China's socialism and its market economy (Brown 2012). ${ }^{(61)}$

Given the positive correlation between corporate governance and rule of law, the movement to make Party leadership the core of corporate governance also reflects the current condition of rule of law in China. Recent comprehensive research by the World Bank found that when a country's overall rule-based corporate governance and rights protection are weak, voluntary and market corporate governance mechanisms have limited effectiveness (Claessens and Yurtoglu 2012). In this regard, it should be noted that the Company Law of China sets out clear rules to empower employee representatives and trade unions to participate in corporate governance, including scope, seat guarantee, and working procedures. ${ }^{(62)}$ In contrast, Article 19 of the Company Law merely permits Party organisations to exist without any detailed stipulation. It is the Party itself that claims and institutionalises its functions and leading role in corporate governance based on its political power. As a result, rule-based governance may have to give way to a less balanced and transparent exercise of political power. Moreover, given the existing environment, any provision concerning the Party organisation may only be implemented and enforced on a one-way street, as Article 19 of the Company Law may only be used to justify the legal status, activities, and resources taken by the Party organisations in companies. It cannot be invoked in legal proceedings as a weapon for the companies and their shareholders to challenge the Party's demands as made at the cost of business efficiency and return on shareholder investment.

This relationship was explained by the CCP in its Decision for rule of law promotion as "Letting Party leadership penetrate the entire process and all aspects of ruling the country by law is a basic experience in the construction of our country's socialist rule of law. (...) Persisting in Party leadership is a basic requirement for socialist rule of law. (...) Party leadership and socialist rule of law are identical; socialist rule of law must persist in Party leadership, and Party leadership must rely on socialist rule of law." (63) Evidently, the CCP

58. Jun Mai, "Xi Jinping is changing the constitution, but what's his endgame?" South China Morning Post, 11 March 2018, https://www.scmp.com/news/china/policies-politics/article/2136676/xijinping-changing-constitution-whats-his-endgame (accessed on 23 July 2018).

59. Yao Dongqin, Li Yonghua and Ho Jun, “企业家为什么这么红” (Qiyejia wei shenme zheme hong? Why are entrepreneurs so red?), Zhongguo Jingji Zhoukan (中国经济周刊, China Economic Weekly) 2017(40): 16-9.

60. Zhou Xincheng, “共产党人可以把自己的理论概括为一句话：消灭私有制” (Gongchandang ren keyi ba ziji de lilun gaikuo wei yijuhua: xiaomie siyouzhi, One sentence to summarise the communist theory: Eliminating private ownership), Qiushi (Seeking Truth), 12 January 2018, http://redchinacn.net/portal.php?mod=view\&aid=34189 (accessed on 26 May 2018).

61. Adair Turner, "A Socialist Market Economy with Chinese Contradictions," The Straits Times, 11 January 2017, https://www.straitstimes.com/opinion/a-socialist-market-economy-with-chinese-contradictions (accessed on 24 October 2018)

62. Such as Art. 17, 18, 44, 51, 67, 108, and 117 of the Company Law of 2013.

63. "Decision of the Central Committee concerning some major questions in comprehensively promoting governing the country according to law), 23 October 2014; https://genius.com/Centralcommittee-of-the-chinese-communist-party-decision-of-the-fourth-plenum-of-the-18th-ccp-ce ntral-committee-english-annotated (accessed on 19 September 2018). 
leadership has been deviating from the pragmatic approach of the early years of reform, and has increasingly reinvigorated Leninist-style governance with a highly instrumentalist attitude towards rule of law (DeLisle 2017: 79).

In spite of totalitarian ideology, the reality after 40 years of reform will impose restrictions on the Party's exercise of power. A dilemma facing the Party-state at this moment is that: on the one hand it has to maintain the momentum of China's economic development as a crucial support for its legitimacy and stability against the "new normal" (xin changtai 新常态) of the market slowdown, where SOEs have long been out-performed by enterprises in the non-public sector; while on the other hand, it has to maintain its control and the monopoly of SOEs for political reasons at the cost of market efficiency. For instance, $\mathrm{Xi}$ jinping once stated that the criteria for measuring the success of SOE reform should be the value increase in state capital, improvement of the state sector's competitiveness, and expansion of state capital control; (64) but at the same time he emphasised Party leadership as "the root and soul" of SOEs (Xi 2016). Apparently, the tested wisdom will pose serious challenges to the party-state for its approach of burning the candle at both ends.

With respect to corporate governance as an important part of a country's institutional competitiveness, there is an interesting debate over the Partystate's control in China. Although some commentators have strongly opposed the party's deeper involvement in SOE governance as moving in the wrong direction, ${ }^{(65)} \mathrm{Xi}$ Jinping firmly believes that the Party leadership is the unique advantage of SOEs (ibid.). In supporting this claim, Professor Jiang Daxing of Peking University further argues that political connections are a phenomenon not only in China, but worldwide, and that such connections are the result of the state's civilised exercise of power to participate in resource allocation with both economic and legal legitimacy (Jiang 2018). He quotes an American scholar, Mara Faccio, to support his view, although the quoted article, which was based on a survey of enterprises in 47 countries, explicitly concluded that "[political] connections are particularly common in countries with higher levels of corruption, countries imposing restrictions on foreign investment. (...) Connections are less common in countries with regulations that set more rigorous limits on political conflicts of interest" (Faccio 2006: 384).

Indeed, some recent surveys have found the rise of state capitalism in many developing countries as an alternative path to the so-called Washington Consensus, with more state intervention, SOE growth, and national champion policies, especially after the worldwide financial crisis in 2008 (Fraser Institute of Canada 2016; The Heritage Foundation 2018). In that sense, what has happened in China is not just a return to the old politics and planned economy, but a style of governance adapted to Western markets and legal institutions and a highly sophisticated strategy to challenge Western leadership in the process of global competition. In other words, the Party-state's distrust of Western corporate governance concepts has led to an upsurge in attempts to find its own answers based on its political path (Allen and Rui 2018). In a larger context, the rise of state capitalism worldwide has also triggered concerns over the stagnation of reform, deterioration of political conditions, repression of market freedom, and negative impact on innovation and protection of private rights (Kurlantzick 2016).

The recent development, however, does call for further research. China, as one of a very few socialist countries with Leninist ideology and with 70 years of communist rule, has made its experience and characteristics unique and complex as compared with other developing countries. Against this backdrop, traditional agency theory, with its focus on conflict of interest between shareholders and management with a contractual nexus, may be too narrow to effectively define the Party's leading role in enterprises (Berle and Means 1967). On the other hand, the more prominent stakeholder theory, with the inclusion of representatives of social and natural systems into corporate governance (Mitroff 1983; Friedman and Miles 2002), may not be able to fully explain the superior position of the Party as a crucial stakeholder in China's socialist market economy. As such, although a large number of empirical studies on China's corporate governance have been conducted, a comprehensive understanding and consensus seems lacking, and further investigations are still needed, particularly on the control mechanism in SOEs as hybrid business entities (Daiser 2016). However, globalised competition and China's ambition to be a leader of trade liberalisation have left the Party-state with much less choice. The issue then seems to boil down to the compatibility of market economy discipline, as reflected in the OECD Principles, with political authoritarianism. The first 30 years of reform tried to make an acceptable compromise in which both the Party-state and market mechanisms had to go through institutional adaptations. The course reversal of the past decade, however, has apparently promoted a new balance in favour of the Party's political rule by reclaiming a considerable portion of the concessions yielded. Such attempts to use political authority to control "the spontaneous extended human order created by a competitive market" (Hayek 1988) may eventually result in frustration of the Partystate's ambition to upgrade its economic structure in worldwide competition due to the constraints of the old path, which caused China to miss its industrial revolution in the last century (Mokyr 2017).

\section{Conclusion}

Since the late 1970s, the Party-state, while vigorously promoting economic and SOE reform, has never ceased to wrestle market institutions with its political powers. The unprecedented intensity of the recent Party leadership campaign in SOEs and other enterprises has brought potential conflict and negative impact, as well as a great deal of uncertainty, to the corporate governance system. This may further affect the long-term development of market sustainability and rule of law in China. At this moment, although it is not completely clear whether the campaign is just a repeat of the "one step forward, two steps back" cycle that has occurred many times in the past 40 years, or the emergence of a new model or approach to institutionalise party-state leadership against market impingement, some problems seem inevitable due to its lack of compliance with the OECD Principles and will surface as this political institutionalisation is fully played out. As a result, further research will be needed to better understand and assess the institutional implications of Party leadership on the market and enterprises.

Xianchu Zhang is Professor of Law at the Faculty of Law, University of Hong Kong (xczhang@hku.hk).

Manuscript received on 22 June 2018. Accepted on 18 January 2019.

64. “习近平'三个有利于'标准是国企改革之魂” (Xi Jinping "san ge youliyu” biaozhun shi guoqi gaige zhi hun, Xi Jinping's "Three Benefits" Criteria are the soul of SOE reform), Zhongguo Jingji Wang (中国经济网, China Economic News), 3 August 2015, http://www.ce.cn/xwzx/gnsz/szyw/ 201508/03/t20150803_6114282.shtml (accessed on 9 April 2018).

65. Sheng Hong, “我为什么不认同这次国企改革” (Wo wei shenme bu rentong zhe ci guogi gaige, Why I do not support this round of SOE reform), Zhongpingwang (中评网 Comments Net of China), 12 August 2016, http://cj.sina.com.cn/article/detail/2381596945/43518 (accessed on 17 May 2018); CaiYong-Wei, "国企改革将开倒车? " (Guogi gaige jiangkai daoche? Will SOE reform be turned back?), Zaobao (早报 Morning Newspaper Singapore), 9 June 2016, https://www.zaobao.com/forum/zaodian/bei-jing-yi-ye/story20160609-626782 (accessed on 1 June 2018). 


\section{References}

ALLEN, Jamie, and Rui LI. 2018. "Awakening Governance - The Evolution of Corporate Governance in China (ACGA China CG Report 2018)." Asian Corporate Governance Association, Hong Kong.

ARMOUR, John, Henry HANSMANN, Reinier R. KRAAKMAN, and PARGENDLER, Mariana. 2017 (3rd ed.). "What Is Corporate Law?" In R. Kraakman et al. (eds.), An Anatomy of Corporate Law: A Comparative and Functional Approach. Oxford: Oxford University Press. Chapter 1.

BERKMAN, Henk, Rebel COLE, and Lawrence FU. 2011. "Political Connection and Minority-Shareholder Protection: Evidence from Securities-Market Regulation in China." Journal of Financial and Quantitative Analysis 45: 1391-417.

BERLE, Adolf Jr., and Gardiner MEANS. 1967 ( $2^{\text {nd }}$ ed.). The Modern Corporation and Private Property: Transaction Books. New York: Harcourt, Brace and World.

BROWN, Kerry. 2012. "The Communist Party of China and Ideology." China: An International Journal 10(2): 52-68.

CLAESSENS, Stjin, and Burcin YURTOGLU. 2012 Corporate Governance and Development: An Update. Washington DC: World Bank.

CLARKE, Donald C. 2010. "Law without Order in Chinese Corporate Governance Institutions." Northwestern Journal of International Law \& Business 30(1): 131-99.

DAISER, Peter. 2016. "Corporate Governance of State-Owned Enterprises: A Systematic Analysis of Empirical Literature." International Journal of Public Sector Management 30(5): 447-66.

DELISLE, Jacques. 2017. "Law in the China Model 2.0: Legality, Developmentalism and Leninism under Xi Jinping." Journal of Contemporary China 26(103): 68-84.

FACCIO, Mara. 2006. "Politically Connected Firms." The American Economic Review 96(1): 369-86.

Fraser Institute of Canada. 2016. "Economic Freedom of the World: 2016 Annual Report." https://www.fraserinstitute.org/sites/default/files/economic-freedom-of-the-world-2016.pdf (accessed on 12 May 2018).

FRIENDMAN, Andrew L., and Samantha MILES. 2002. Stakeholders, Theory and Practice. Oxford: Oxford University Press.

GORE, Lance L. 2011. The Chinese Communist Party and China's Capital Revolution: The Political Impacts of the Market. London: Routledge.

HAYEK, Friedrich A. 1988. The Fatal Conceit: The Errors of Socialism. Chicago: University of Chicago Press.

The Heritage Foundation. 2018. "2018 Index of Economic Freedom." https://www.heritage.org/index/pdf/2018/book/index_2018.pdf (accessed on 12 May 2018).

International Trade Administration of US (ITA). 2017. "China Country Commercial Guide: State Owned Enterprises." https://www.export.gov/ article? id=China-State-Owned-Enterprises (accessed on 13 September 2018).

JENSEN, Michael C., and William H. MECKLING. 1976. "Theory of Firm: Managerial Behavior, Agency Costs, and Ownership Structure." Journal of Financial Economics 3(4): 305-50.

JIANG, Daxing 蒋大兴. 2018. “政治/政党与企业- 政治权利参与资源分配 的文明结构” (Zhengzhi/zhengdang yu qiye - zhengzhi quanli canyu ziyuan fenpei de wenming jiegou, Politics/political party and enterprises: A civilized structure for participation of political powers into resource allocation). Dangdai Faxue (Contemporary Law Review) 1: 11-31.

JOHANSSON, Anders, and Xunan FENG. 2016. "The State Advances, the Private Sector Retreats? Firm Effects of China's Great Stimulus Programme." Cambridge Journal of Economic 40(6): 1635-68.
KURLANTZICK, Joshua. 2016. State Capitalism: How the Return of Statism Is Transforming the World. Oxford: Oxford University Press.

LIAO, Wenjing 廖文静. 2017. “国有控股上市公司治理结构研究” (Guoyou konggu shangshi gongsi zhili jiegou yanjiu, A corporate governance study of listed companies with state controlling holdings). Qiye yu Gaige (Enterprise and Reform) 11: 4-5.

LIN, Li-Wen, and Curtis J. MILHAUPT. 2013. "We Are the (National) Champions: Understanding the Mechanisms of State Capitalism in China." Stanford Law Review 65(1): 697-759.

MILHAUPT, Curties L., and Wentong ZHENG. 2016. "Why Mixed-Ownership Reforms Cannot Fix China's State Sector." Paulson Institution Policy Memorandum. http://www.paulsoninstitute.org/wpcontent/uploads/ 2017/01/PPM_SOE-Ownership_Milhaupt-and-Zheng_English_R.pdf (accessed on 23 May 2018).

MITROFF, Ian. 1983. Stakeholders of the Organizational Mind. San Francisco: Jossey-Bass.

MOKYR, Joel. 2017. A Cultural of Growth:The Origins of the Modern Economy. Princeton: Princeton University Press.

OECD. 2015. G20/OECD Principles of Corporate Governance. Paris: OECD.

OECD. 2015. OECD Guidelines on Corporate Governance of State-Owned Enterprises (2015 ed.). Paris: OECD.

SONG, Houze. 2017. "State-Owned Enterprise Reforms: Untangling Ownership, Control, and Corporate Governance." Paulson Institute. http://macropolo.org/wp-content/uploads/2017/12/State-Owned-Enterprise-Reforms.pdf (accessed on 23 February 2018).

TIAN, Fangmeng. 2017. "Millionaire Emigration:The Allure of Investor Visas among China's Elite." Migration Policy Institute, 20 September 2017. https://www.migrationpolicy.org/article/millionaire-emigration-allure-investor-visas-among-chinas-elite (accessed on 5 April 2018).

Unirule Institute of Economics. 2016. “国有企业的性质、表现与改革” (Guoyou qiye de xingzhi, biaoxian yu gaige, The nature, performance and reform of SOEs) http://unirule.cloud/index.php?c=article\&id=4017 (accessed on 24 December 2017). United States Trade Representative. 2015 Report to Congress on China's WTO Compliance.

WANG, Jiangyu. 2014. "The Political Logic of Corporate Governance in China's State-Owned Enterprises." Cornell International Law Journal 47(3): 632-64.

The World Bank. 2017. Governance and the Law (World Development Report 2017). The World Bank. 83-4.

The World Trade Organization (WTO). 2001. Report of the WTO Working Party on the Accession of China.WT/ACC/CHN/49.

WEl, Chuyi. 2017. "Bailouts and Bankruptcy Law in China: A Confusion of Law and Policy." Cambridge Journal of China Studies 12(4): 50-75.

Xl, Jinping 习近平. 2016. “坚持党对国有企业的领导不动摇” (Jianchi dangdui guoyou qiye de lingdao budongyao, Unswervingly adhering to the party leadership in SOEs). Renmin Ribao (人民日报 People's Daily), 12 October 2016.

YANG, Dali, and Junyan JIANG. 2012. "Guojin Mintui: The Global Recession and changing State-Economy Relations in China." In Dali L. Yang (eds.), The Global Recession and China's Political Economy. New York: Palgrave MacMillan.

ZHANG, Xianchu. 2012. "Company Law Reform in China." In John Garrick (ed.), Law and Policy for China's Market Socialism. New York: Routledge. Chapter 2. 